\title{
Redirecting National Parliaments: Setting Priorities for Involvement in EU Affairs
}

Pieter de Wilde

WZB Berlin Social Science Center

Department of Global Governance

Reichpietschufer 50 DE-10785 Berlin

Germany

pieter.dewilde@wzb.eu

Tel: +49 3025491191
Tapio Raunio

University of Tampere

School of Management

FI-33014 Tampere

Finland

tapio.raunio@uta.fi

Tel: +358407332653

\begin{abstract}
While national parliaments in the European Union have learned to internalize new opportunities for influence given to them by the Lisbon Treaty, European integration has evolved and places ever more serious demands and constraints on domestic legislatures. Following the euro crisis, key decisions about national macro-economic policies are taken in the European Council and the European Semester. These are the issues traditionally at the heart of both democratic governance and citizens' concerns. Relating these developments to the key functions national parliaments ought to perform, we develop the normative argument that a redirection of national parliaments' resources away from less salient matters and particularly the Early Warning Mechanism toward the European Council and European economic governance would be welcome.
\end{abstract}

\section{Key words}

National parliaments, EU, Early Warning Mechanism, European Council, euro area 


\section{Introduction}

In May 2012, the first so-called 'yellow card' was wielded by national parliaments under the Early Warning Mechanism (EWM), stating that a legislative proposal of the Commission was in breach of the subsidiarity principle. To accomplish this, at least one third of national parliaments of European Union (EU) member states sent a reasoned opinion to the Commission within eight weeks of the publication of the legislative proposal. The EWM has been in operation since the entry into force of the Lisbon Treaty in 2009, and parliaments have slowly increased their activity within the mechanism (Gattermann and Hefftler, 2015) - sending more and more reasoned opinions to the Commission - yet the threshold to draw a yellow card had never been reached until that point. The legislative proposal in question that finally provoked a yellow card - Monti II - concerned the 'exercise of the right to take collective action within the context of the freedom of establishment and the freedom to provide services' (Barrett, 2012; Fabbrini and Granat, 2013; Goldoni, 2014; Cooper, 2015). Some observers welcomed this event as a breakthrough in the (effective) involvement of national parliaments in the EU and even as the 'vindication of national parliaments as a virtual third chamber in the EU' (Cooper 2013; Paulo 2012). The second yellow card wielded against the proposal to establish a European Public Prosecutor's Office (EPPO) substantiates such views. More sceptical reviews of the EWM criticize the functioning and effectiveness of the mechanism, arguing it is unlikely to work or have much effect in practice. ${ }^{1}$

The availability of the EWM as instrument of parliamentary influence in EU affairs and its 'success' as evidenced in the two yellow cards to date make it tempting for national parliaments to divert considerable resources to this mechanism. In its evaluation report from 2011 about EU 
affairs, the Dutch Tweede Kamer $(2011,8)$ stated: 'The evaluation committee is of the opinion that the Tweede Kamer should continue its efforts on all levels and in all forums to apply the yellow, or even the orange card, so that the position of national parliaments in EU affairs is not just strengthened on paper, but also in practice.' Not only do reasoned opinions need to be drafted and sent to the Commission before the end of the eight week deadline, but extensive lobbying of other national parliaments to also send in reasoned opinions is required in order to reach the threshold for a yellow card. To facilitate this, national parliaments have set up considerable support staff for EU affairs, which Christiansen et al. (2014) fear may lead to a 'bureaucratisation rather than democratisation' of national parliamentary involvement in EU affairs.

In contrast to those welcoming parliamentary activity under the EWM and to those sceptic about whether the EWM can function effectively, we provide fundamental criticism embedded in a broad normative perspective on parliamentary democracy and the state of the Union. As parliamentary resources are limited, we draw attention to opportunity costs attached to activity within the EWM framework. By steering parliamentary activity towards the EWM, attention and resources are drawn away from parliaments' two core functions: controlling governments and connecting to citizens. Faced with ever more demands and opportunities for involvement in EU governance, we provide normative arguments based in democratic theory and drawing from empirical developments in European integration why national parliaments should prioritize either major issues in European integration or those EU matters that are otherwise domestically more salient. In practice, this means focusing more on the European Council where major questions about Treaty revision, enlargement, foreign policy and macro-economic governance are 
effectively decided. In light of the euro crisis, the main efforts of national parliaments in EU affairs should be directed at the European Semester in which the macro-economic topics at the heart of democratic governance and citizens' concerns are dealt with: economic growth, employment, inflation, taxation and redistribution. With such a focus, parliaments would be much more effective in controlling their national governments and in communicating with citizens in both national and EU affairs.

The argument we provide thus concerns what national parliaments in EU framework should do, but it cannot be considered as a recipe ready for implementation across the Union. That would require tailor-made feasibility studies and prescriptive implementation plans for each national parliament separately. However, underlining that 'ought implies can', we draw attention to what we consider to be successful yardsticks of what we call for. We start out with outlining the core functions national parliaments should perform in any democratic polity and how these are related to the multi-level structure of the EU. Then, we explain briefly how the EWM works in the next section, discuss its empirical track record to date and relate it to these core functions of parliaments. The fourth section discusses developments in the EU since the ratification of the Lisbon Treaty - with a particular focus on the European Council and the euro crisis - and parliamentary involvement therein. Finally, the conclusion summarizes our main argument and identifies remaining challenges.

\section{The functions of national parliaments and EU governance}

Although there are different categorizations of parliamentary functions in the literature, these generally fall into two groups: controlling the government and providing an arena for public 
debate. Bagehot (1867) compiled a list of five functions: the elective function (choosing the cabinet), expressing the mind of the people, teaching the nation, informing the people, and the legislative function. The 'classic' text is arguably Packenham (1970), who divided his eleven functions into three categories: legitimation: latent (meeting regularly), manifest (formally approving public policy), safety valve or tension release (outlet for tensions); recruitment, socialization and training; and decisional or influence functions: law making, 'exit' (resolving an impasse on the system), interest articulation, conflict resolution, and administrative oversight and patronage (including 'errand running' for constituents). As governments have become increasingly responsible for initiating legislation, the control and legislative functions of parliaments have largely fused into one (King, 1976). Norton (1993) then reworked Packenham's list and divided the functions into two groups: those that relate to the government (including both government oversight and legislation) and those that focus on parliament's links with the citizens. It follows, that the quality of institutional innovations like the EWM can be assessed against the benchmarks of these functions.

In EU politics ${ }^{2}$, MPs hold the government accountable for its actions and try to make sure that it acts in correspondence with the will of the parliamentary majority - as they do in domestic politics. Most studies on the role of national parliaments in the EU have focused on the control or scrutiny function. This literature informs us that domestic legislatures employ a wide range of control mechanisms for holding the government accountable, but the most notable are the European Affairs Committees (EAC) that exist in the parliaments of all member states. There remain, however, strong national differences as to both how powerful EACs are and the extent to 
which the regular standing committees become involved in EU affairs (e.g. Hefftler et al., 2015; Auel and Christiansen, 2015; Karlas, 2012; Winzen, 2013a; 2013b).

Turning to the functions that relate to the linkage between citizens and legislatures, parliaments are (or should be) a central institutional arena for public deliberation and will-formation for two reasons. Firstly, arguments about European integration should be exchanged in an effort to reach optimal policies in a process of rational deliberation where the best argument wins (Eriksen and Fossum, 2002). Secondly, debates are needed through which party positions on EU issues can be signaled to voters. Not only can citizens thereby learn which issues are currently high on the political agenda, but it also allows voters to recognize which party best represents their interests and thereby informs their votes in the next election (Føllesdal and Hix, 2006; Mair, 2007).

Empirical studies on the communicative function of national parliaments highlight the disconnect between citizens and elites, with parliamentary EU discussions mainly confined to the relatively closed environment of EACs and other committees (Auel, 2007; Auel and Raunio, 2014). Parliaments, however, debate major EU issues like Treaty reforms or the euro crisis in plenary, accentuating conflicts between opposition parties and the governing coalition as well as ideological conflicts between the left and the right (Maatsch, 2014; Wendler, 2013). It is furthermore noted that mechanisms designed to strengthen the control of national parliaments have a significant effect on the way parliamentarians debate EU issues as ex ante scrutiny generates less visible debates, but with clear difference of opinion among parties, while ex post scrutiny generates more visibility, but with stronger substantial consensus among parties (De Wilde, 2011; 2014). 
To conclude, we find consensus among scholars that the main functions of parliaments relate on the one hand to government (oversight and legislation) and on the other hand to citizens (informing and aggregating preferences through providing an arena for public debate). ${ }^{3}$ When assessing the involvement of national parliaments in EU affairs, we should thus ask ourselves whether existing institutional devices and the activities of parliaments within them strengthen either one of these groups of functions, and preferably both.

\section{The EWM and the core functions of parliaments}

It must be emphasized from the outset that EWM was not primarily designed either to facilitate government accountability or to link parliaments or the EU with citizens, but to inject legitimacy to European governance. To quote Rittberger $(2005,192)$ it was 'a logical and widely accepted argument that the political institutions that were seen to have suffered most from ever more transfers of sovereignty to the European level - [national parliaments] - should be entitled to have a say regarding the application of the principle of subsidiarity, putting - if deemed necessary - a brake on the appropriation of policy-making competencies by the Commission.'

Let us briefly introduce how the EWM works. Through the mechanism, national legislatures are assigned the right to monitor whether initiatives for EU laws comply with the principle of subsidiarity according to the rules explained in the Protocol on the Application of the Principles of Subsidiarity and Proportionality. In practice, this means that they check whether the legislative instrument proposed is really needed at EU rather than national level and whether its degree of restriction is attuned to the severity of the problem it aims to address. Under this 
mechanism, a national parliament can, within eight weeks from the date of transmission of a draft legislative act, send the EU institutions (primarily the Commission) a reasoned opinion stating why it considers that the legislative initiative does not comply with the principle of subsidiarity. National parliaments may, where appropriate, consult regional parliaments with legislative powers. Each national parliament has two votes and in bicameral systems each of the two chambers has one vote. If the reasoned opinions represent at least $1 / 3$ of all the votes allocated to the national parliaments ('yellow card'; $1 / 4$ in the case of draft legislative acts falling under Article 76 of the Treaty on the Functioning of the European Union on the area of freedom, security and justice), the draft must be reviewed. After the review, the Commission may decide to maintain, amend or withdraw the draft.

An additional procedure is in force under the ordinary legislative procedure. If the reasoned opinions represent at least half of the total votes allocated to national parliaments ('orange card'), the opinions of both national parliaments and the Commission are submitted to the European Parliament (EP) and the Council. If $55 \%$ of the members of the Council or a simple majority in the EP agree that the proposal breaches the principle of subsidiarity it shall not be given further consideration. Finally, where a national parliament believes that the adopted law infringes the principle of subsidiarity, it may ask its national government to bring a case before the Court of Justice of the European Union (CJEU).

The question we therefore ask is whether the EWM supports either the control or the communicative functions of national parliaments effectively. Let us first turn to the control functions. Considering the EWM and the broader upgrading of the role of national parliaments 
by the Lisbon Treaty, it is not surprising that there are stronger expectations regarding domestic legislatures in EU governance. In this new post-Lisbon environment, so the argument goes, domestic legislatures have new tools at their disposal, and this broadened toolkit provides them incentives to become more strongly involved in EU affairs. Many commentators have hoped or argued that the EWM will increase the 'ownership' of European matters among national MPs. It can make national parliaments feel that they have a say in the EU policy process and this can produce a potentially significant 'spill-over' effect, making at least some of them invest more resources in scrutinizing EU matters. It can also improve the quality of EU governance by forcing the Commission to be more detailed in its justification for new legislative proposals and in general more sensitive to national concerns. ${ }^{4}$ To the extent that national parliaments actively collaborate under the EWM - and especially when meeting the threshold of a yellow or orange card as in the cases of the Monti II regulation and the EPPO - they arguable constitute a 'virtual third chamber' (Cooper, 2012; 2013), thus exercising simultaneously their 'network' and 'gatekeeping' functions (Sprungk, 2013). That is, they act collectively to prevent legislative proposals from becoming law. ${ }^{5}$

We do not dispute this logic. Regardless of whether national parliaments can influence the EU legislative process through yellow or orange cards, the increasing number of reasoned opinions submitted to the Commission shows that many parliaments view the EWM as a worthwhile instrument and appreciate the opportunity to engage in direct dialogue with the EU institutions. EWM can provide national parliaments some measure of control over European legislation and 'creeping competences'. Parliaments with weaker participation rights in EU affairs, such as those without formal mandating powers, can also submit reasoned opinions in order to put pressure on 
their own government. Moreover, often parliaments have deliberately adopted a flexible approach to EWM, including substantive policy opinions in their reasoned opinions in the hope of shaping forthcoming legislation (e.g., Kiiver, 2012). The success in the Monti II and EPPO proposals may provide further incentives for national legislatures to invest resources in subsidiarity checks - and may thereby contribute to overall parliamentary scrutiny of EU draft laws. The literature also indicates that several parliaments, such as the Portuguese Assembleia, have indeed introduced in the post-Lisbon era reforms which can trigger more effective oversight of EU matters (e.g. Jančić, 2012; Neuhold and Strelkov, 2012; Hefftler et al., 2015). The interparliamentary networking produced by EWM, occurring mainly either online between parliamentary administrations or between the Brussels-based representatives of national parliaments, can also be beneficial, resulting in more effective use of EWM and in more regular exchange of information among national parliaments (Högenauer and Neuhold, 2015; Christiansen et al., 2014).

However, networking and constituting a collective actor in EU affairs are not among the core functions of national parliaments. Only if these activities strengthen the control over the national government or reinforce communication with national citizens in cost-effective ways can we conclude that such activities are normatively justified. Parliaments might constitute a 'virtual third chamber', but the question we should ask is whether subsidiarity checks, reasoned opinions and interparliamentary lobbying to reach the yellow card threshold result in tighter cabinet scrutiny and/or more informed citizens. ${ }^{6}$ Given that most of the parliamentary activity in the EWM, both in individual chambers or in interparliamentary cooperation at the EU level, is carried out by parliamentary civil servants (Högenauer and Neuhold, 2015), it is doubtful that the 
mechanism produces higher 'ownership' of EU affairs among domestic MPs. The EWM is also very demanding for those MPs that want to become involved in the checks, as they need knowledge both of EU law and the actual policy area to determine whether a proposal is in breach of the subsidiarity principle. Turning to how legislatures link with citizens, the same literature informs us that subsidiarity checks are by and large conducted by parliamentary clerks in the EAC or in standing committees. And while there is no data available at the level of individual MPs or party groups, it is doubtful that they interact with their electorates about subsidiarity checks (Peters, 2009, 42). ${ }^{7}$ Even if there are thus 'spin-off' effects by creating greater awareness among MPs about EU affairs through the EWM, we should ask whether the same effects cannot be reached in more direct and cost-effective ways, such as through strengthening EACs or other scrutiny procedures vis-à-vis the national government or attuning public parliamentary activity to maximize the audience exposed to parliamentary debate.

While the EWM can thus benefit national parliaments and even the quality of EU governance, we stress the fact that the existing literature so far does not relate EWM activity to the core functions of parliaments nor questions its cost-effectiveness in relation to opportunity costs. The latter may well outweigh any potential benefits. The mechanism presents clear opportunity costs in terms of time and manpower that national parliaments now spend on subsidiarity checks and reasoned opinions which cannot be spent on other activities. The EWM distracts from the scarce parliamentary resources that could be devoted to either directly controlling the governments or to accounting to citizens in EU affairs. Were these existing mechanisms operating at peak effectiveness, an argument could be made for improving democratic quality by adding new mechanisms. However, there are strong reasons to believe that neither parliamentary control nor 
communication with citizens in EU affairs function optimally. While most national parliaments have gradually consolidated their positions in EU affairs, there remains significant variation between the legislatures regarding both their constitutional or legal rights and actual scrutiny or debating activities. Many weaker parliaments lack any real mandating powers, become only sporadically involved in European matters, and find it often even difficult to secure relevant information from the government, while even the strongest legislatures, such as those of Denmark or Finland, are struggling to keep pace with developments at the European level, whether in the context of early agreements in the co-decision procedure or in the rapidly changing circumstances of the euro crisis (Auel and Christiansen, 2015; Hefftler et al., 2015; Winzen, 2013a; 2013b). We have to be careful here not to exaggerate the amount of EAC or parliamentary staff resources assigned to EWM, but the key observation is that even for parliaments with cost-efficient procedures time devoted to subsidiarity checks cannot be spent on other EU affairs - such as selection of key documents (see the next section) or producing information for MPs or citizens.

The Monti II yellow card provides a useful case to examine our arguments. Regarding government control, it is questionable whether the yellow card influenced national governments. In some member states, the government actively suggested that parliament send a reasoned opinion to the Commission. In others, like Spain, the government actively prevented parliament from sending an opinion. In Denmark, where the push towards the yellow card initiated, the government had already indicated its political objection to Monti II before the Folketing wrote its reasoned opinion (Cooper 2015). In the end, Cooper (2015) and Barrett (2012) conclude that the chances were high that Monti II would not have made it through the legislative process in the EU 
even without a yellow card, as there appeared significant objection within the major party groups in the EP and certainly no consensus in favour within the Council. It is thus hard to argue that the yellow card contributed to the control functions of national parliaments.

\section{TABLE 1}

This non-finding is corroborated through a LexisNexis search in newspaper archives (Table 1). A search in 14 quality newspapers in the UK, Germany, France, the Netherlands, Ireland and Austria for both yellow cards resulted in a total of 5 hits, four of which were in one single Dutch newspaper. Moreover, the sparse coverage did not cover the substance of the respective proposals in depth, but focused rather on the abstract principle of the subsidiarity check and its meaning for the institutional balance of power between EU and national institutions and its implications for democratic legitimacy of the EU. While the Monti II yellow card was somewhat framed as a victory of leftist parties over a move toward further liberalization, the political component of EPPO remained obscure. The positive potentials of the EWM in shaping legislation were thus not supported.

Further searches reveal that the yellow cards in Monti II and EPPO cases were reported on specialized EU news websites (such as EurAktiv.com, EUObserver.com and Europolitics.info) as well as on the websites of several labour organizations and MEPs. However, no major frequently visited news site - like the online portals of newspapers or public broadcasting companies - even mentioned them. The yellow card thus seems to have reached only a small niche public of already highly interested people. Without broader resonance in mass media, most 
citizens will not be informed about the activities of national parliaments, the issues at stake, or the positions and arguments of their elected representatives. In other words, the communicative functions of national parliaments are hardly directly supported by the EWM, even in the exceptional cases in which it 'worked': the Monti II regulation and EPPO proposal. Out of our sample of 14 European newspapers, only the elite center-right readership of the Dutch NRC Handelsblad was exposed to a more thorough coverage of the yellow cards.

\section{European Council and European economic governance}

The EWM is of course only one possible way for national parliaments to become involved in EU affairs. Given the scarcity of parliamentary resources, domestic legislatures need to make choices and prioritize. Despite the increasing domestic politicization of Europe (Hooghe and Marks, 2009), it is safe to argue that for most MPs 'domestic politics' come ahead of EU affairs. This means that any national parliament, including its EAC, cannot subject all European matters to careful committee scrutiny or plenary debates. Linking our arguments again to the core functions of parliaments, we highlight in this section the need for parliamentary oversight of the European Council and European economic governance.

Academic research, political debate, and the EU Treaties have emphasized domestic parliamentary accountability of Council meetings which largely takes place through EAC meetings and mandates. What has long been overlooked by parliaments and academic observers alike, yet has recently drawn more attention, is parliamentary involvement around European Council meetings (De Wilde, 2011; Wessels et al., 2013). The European Council effectively decides major issues of European governance, like Treaty changes, EU's grand strategy and 
responses to military conflicts, enlargement and the multi-annual EU budgets. It has steadily grown to become the most influential executive institution in the EU (Van Middelaar, 2009). Most decisions are taken unanimously which should provide stronger incentives for national parliamentary accountability, because legislatures could effectively block decisions if they manage to control their government's actions. Because of the conflictual nature of the meetings along country lines, the personalization thereof by the prime ministers, the late hour suspense whether compromises can be reached and the high importance of the issues discussed, the European Council meetings tend to generate massive media coverage (De Vreese, 2001). If parliaments time their activities close to such meetings, they can piggyback on the temporary wave of media attention to get their activities, arguments and internal conflicts communicated to citizens.

The outbreak of the euro crisis further accelerated the trend of the European Council becoming the key locus of EU governance and public attention for EU affairs. This development is explained by two factors. First, the agenda of the European Council has in recent years been increasingly dominated by topics that are at the heart of citizen interest: inflation, employment, government debt and the 'economic situation' (Figure 1). These issues may be particularly salient now across the EU in light of the euro crisis, but the ranking of issues was already the same before the crisis started (cf. Moravcsik, 2006, 224). We also know from both country studies and comparative surveys that such major socio-economic questions have tended to dominate national electoral campaigns in basically all EU member states (e.g. Caramani et al., 2011). 


\section{FIGURE 1}

Secondly, the powers and activity of the European Council have increased tremendously in European economic governance. Decisions about the bailouts of Greece and other member states, the creation of the banking union and European Semester are all effectively made in the European Council. With the entry into force of the European Fiscal Compact (Treaty on Stability, Coordination and Governance in the Economic and Monetary Union), there are now specific Eurozone summits and national budgets are coordinated in yearly 'European Semesters'. These include strong Council and Commission recommendations regarding national budgets with severe sanctions possible should these not be heeded. Not only do these financial and budgetary decisions stand at the heart of the European Council agenda and citizen concerns, but they also traditionally form the 'crown jewel' (Puntscher Riekmann and Wydra, 2013, 567) of representative parliamentary democracy as they combine the key questions of taxation, state power over society and redistribution (Kahn, 1997). Thus, if national parliaments are to perform their functions of controlling government and communicating with citizens in EU affairs effectively, they should direct their main activities toward issues decided upon in the European Council. This is because: a) key decisions in European economic governance are made in this arena; b) the requirement of unanimity voting allows the possibility of strong parliamentary control; c) citizens care most about these issues; and d) media coverage of such events is high, providing parliaments with a platform to reach citizens.

While most national parliaments have now set up some mechanisms to deal with European Council affairs, much of parliamentary oversight remains geared to the ordinary legislative 
procedure, scrutinizing Commission proposals and government behaviour in the Council. Some generally more 'Europeanized' parliaments, like the Danish Folketing, the Dutch Tweede Kamer and those of the Baltic states also enjoy substantial powers towards European Council meetings. But this is not common place, as according to a detailed study conducted in 2012 only 17 of 27 national parliaments had formal rules dealing specifically with European Council meetings (Wessels et al., 2013, 42).

The situation surrounding the European Semester is decisively more dismal. Under the European Semester, national governments are asked to send plans for long-term budgetary planning Stability or Convergence Programmes (SCPs) - to the Commission for recommendations and deliberation in the Council. The most recent research suggests that there is considerable variation between national parliaments in their involvement in euro crisis governance. Differences between more active and weaker legislatures have been aggravated, with the latter in particular struggling to establish any real control over euro area decisions (Auel and Höing, 2014; 2015; Benz, 2013; Deubner, 2013, Rittberger and Winzen, 2015). The inevitable conclusion must be that domestic parliamentary scrutiny of European economic governance is far from optimal. ${ }^{8}$

Some observers note that parliamentary involvement around the European Council is highly 'national', meaning that the main focus is on the national interest and how government can defend it (e.g. De Wilde, 2011; Puntscher Riekmann and Wydra, 2013; Wessels et al., 2013, 59). From the perspective of government control and communicating with citizens, the focus on defending the national interest can be unproblematic as long as there is a free debate about what that national interest substantially entails. This is, after all, what both national governments and 
national parliaments should do: further the national interest. In addition, due to strong remaining national identity perceptions of citizens (Hooghe and Marks, 2009) and a focus on domestic relevance by mass media, such framing tends to resonate highly with the public (Bruter, 2009; De Vreese, 2007; De Wilde, 2012), thus strengthening the communicative functions of parliaments.

The problem is, however, that substantial policy choice tends to be reduced in the process. Rarely is there an objective coherent 'national interest' that all citizens of a particular country share. Instead, the focus on the national interest tends to propel one particular interpretation thereof to the forefront while crowding out certain interests held by citizens and other possible interpretations of what the national interest is. Furthermore, by framing the debate and the government position in terms of 'national interest', it becomes difficult for the whole parliament and the opposition parties to challenge its substance as this is easily equated with treason (Benz, 2004). But without substantial policy choice offered by different political parties, citizens are deprived of political efficacy during the next elections as there are no alternative government programs to choose from. Care should thus be taken not to reduce parliamentary activity to the periods just before or after European Council meetings. Parliaments should instead work on anticipating the agenda of European Council meetings well in advance, so that time can be taken debating what exactly the national interest (i.e. government negotiation strategy) should be. Such a pro-active approach is clearly needed: in the context of euro crisis decision-making national parliaments have questioned whether they can genuinely debate and examine the issues, a concern that is understandable given the complexity of the situation, the need by the member states to achieve quick results, and the high number of European Council and other EU meetings 
that deal with the eurozone crisis (COSAC, 2013; Puntscher Riekmann and Wydra, 2013). Still, for reasons spelled out above, we deem it imperative that national parliaments hold public hearings around European Council meetings to control government and communicate with citizens about the issues at the very heart of citizens' concern and parliamentary democracy.

Moving beyond European Council meetings and European economic governance, there are other EU affairs that deserve closer attention from national parliaments. While there are major EU issues ranging from euro crisis to Treaty reforms that are salient for all parliaments, the situation is most likely different with ordinary European legislation or other EU policy processes. That is, the salience of such day-to-day EU matters probably varies between member states, depending for example on the structure of the economy or the geographical location of the country. A careful reading of the literature indicates that in all parliaments only a small minority of 'normal' EU issues receive more detailed committee scrutiny or inspire plenary debates (Maurer and Wessels, 2001; O’Brennan and Raunio, 2007; Tans et al., 2007; Barrett, 2008a; Hefftler et al., 2015). This applies to even those parliaments, such as in Denmark or Finland, that have more comprehensive formal scrutiny systems, with the EAC agendas featuring every forthcoming Council meeting and other European matters as well.

While there are (as of yet) no empirical studies on issue selection by domestic legislatures in EU affairs, there is evidence that, at least in some member states, the level of parliamentary scrutiny is explained by the importance of co-decision legislation or the incentives of government and opposition parties (De Ruiter, 2013; Finke and Dannwolf, 2013). However, at the same time the literature suggests that MPs or party groups often learn about the implications of EU proposals 
via 'fire alarms' (McCubbins and Schwartz, 1984), through lobbying by interest groups and other interested actors (Sprungk, 2013). For example, even the Services Directive, according to many the most important European law since the turn of the millennium, was noticed by Austrian and German MPs only after trade unions and other interest groups had expressed serious concerns about the initial Commission proposal (Miklin, 2014). It thus appears that parliaments and their EACs should perhaps be more selective, and focus on those normal EU issues that are genuinely domestically salient.

We do not deny that it can be useful, particularly from the point of view of government accountability, to demand information and hear ministers about all matters on the agendas of the Council so that MPs can intervene if needed, but parliaments could engage in more forwardlooking issue selection with the help of either national or EU documents such as the Commission's annual legislative programme. The comparative literature referred to above does suggest that parliaments - and particularly their administrations (Högenauer and Neuhold, 2015) - do perform such filtering of EU issues, but more could be done to prevent information overload and to facilitate more targeted scrutiny. Again this would be beneficial for both government oversight and communication with citizens, as more attention would be given to those matters that are domestically salient. As argued convincingly by Winzen (2013a, 153):

'What would it really tell us, if we were to find that parliaments examine each and every of the EU's legislative proposals in detail, instructing the government what goals to pursue in the negotiations? ... The benchmark for well-functioning oversight institutions in EU affairs is not that they exacerbate time shortages by making parliament deal with all EU 
activities, but to help parliament put the time it devotes to EU affairs to the best use. Thus, oversight institutions should help parliaments select the matters that are worth the parliament's time.'

\section{Conclusion}

This article has provided a critical analysis of the involvement of national parliaments in EU affairs since the ratification of the Lisbon Treaty. Our criticism is particularly directed at the Early Warning Mechanism, seen by many as an innovation that upgrades the role of national parliaments in modern Europe and contributes to the legitimacy and democracy of EU governance. We have argued that the EWM, while not worthless, strengthens neither of the two sets of core functions parliaments ought to perform in parliamentary democracy directly: controlling government or communicating with citizens. We have emphasized the need for parliaments to 'redirect' their activities more towards the European Council, euro area economic governance, and other domestically more salient matters. This would improve the parliamentary accountability of both national and EU politics and would ensure that the parliamentary processing of European matters receives more media coverage.

Domestic legislatures have a highly important role in EU governance. But at the same time both academics and politicians need to be realistic and refrain from expecting too much from national parliaments. With the EWM, national parliaments have one more potential avenue for participating in EU politics - and the more participation rights parliaments have, the more they need to prioritize what to focus on. Parliamentarians face competing demands on their time, and despite the increasing relevance of the EU, it is logical for MPs and for parliaments to delegate 
many of the EU matters to governments. In fact, it appears that the subsidiarity checks are mainly carried out by parliamentary clerks, further limiting the potential beneficial side effects of the EWM on either government control or communication functions.

Our critique of parliamentary involvement in the EU has been positive in the sense that we call for more active parliamentary involvement, not less. In terms of electoral competition, policy outputs, or constituency interests, Europe simply matters more for national parties and their MPs than it did before Lisbon. The more Europe matters, the stronger the arguments for MPs to engage in EU politics. We therefore welcome improvements in EU scrutiny procedures by national parliaments. Stronger oversight of European Council and European economic governance requires procedural changes that facilitate pro-active control of these key issues in most parliaments. We note and even hope, however, that limited parliamentary engagement with European economic governance to date may be a result of the relative novelty of the euro crisis and that time for parliamentary learning is needed to improve the current situation.

Government oversight or holding veto power over Treaty amendments are not the only way in which national parliaments contribute to the legitimacy of twenty-first century European governance. Indeed, the lack of domestic debates on Europe is often seen as a significant component of the democratic deficit. For example, Peter Mair (2007) argued convincingly that European integration contributes to the depoliticization or 'hollowing out' of modern European governance and of national democracy in particular. Not everyone may want such debates: many political parties continue to have electoral reasons not to engage in public conflicts over integration. However, the salience of European Council meetings, macro-economic governance, 
budgetary policies and other domestically important matters can generate plenary debates given the opportunity, thereby strengthening the communicative functions of parliaments in EU affairs. In a nutshell, national parliaments can best contribute to European democracy by doing in European politics exactly what they do in domestic politics - scrutinizing government and publicly debating important policies in committees and the plenary.

\section{Acknowledgements}

Previous versions of this paper were presented at the TU Dresden International Politics colloquium, January 2014 and the first PADEMIA annual conference in Brussels, June 2014. The authors thank all the participants at those events for their comments.

\section{About the Authors}

Pieter de Wilde is Senior Researcher at the WZB Berlin Social Science Center. He is a member of the WZB project 'the Political Sociology of Cosmopolitanism and Communitarianism' and the Department of Global Governance. His research interests include cleavage formation between cosmopolitans and communitarians, Euroscepticism, the politicization of European integration and the involvement of national parliaments in the EU. He holds a $\mathrm{PhD}$ in political science from ARENA, Center of European Politics at the University of Oslo and a MSc in political science from the University of Amsterdam. His articles have been published in Comparative European Politics, European Journal of Political Research, European Political Science Review, Journal of Common Market Studies, Journal of European Integration, and Journal of European Public Policy among others. 
Tapio Raunio is professor of political science at the University of Tampere. His research interests include legislatures and political parties, the Europeanization of domestic politics, semipresidentialism and the Finnish political system. He has published articles in journals such as Comparative European Politics, European Journal of Political Research, European Union Politics, Journal of Common Market Studies, Journal of European Public Policy, Party Politics, Scandinavian Political Studies and West European Politics. He is the co-author of Finland in the European Union (2003, with Teija Tiilikainen), and the co-editor of National Parliaments within the Enlarged European Union: From victims of integration to competitive actors? (2007, with John O'Brennan) and Connecting with the Electorate? Parliamentary Communication in EU Affairs (2014, with Katrin Auel).

${ }^{1}$ EWM and more broadly the upgrading of the role of national parliaments by the Lisbon Treaty have generated quite a lot of academic interest. However, given that the Lisbon Treaty has only been in force since late 2009 , understandably the findings of this literature are quite tentative (see particularly Cygan, 2013; Cooper, 2012; 2013; 2015; Kiiver, 2012; Bellamy and Kröger, 2014; Gattermann and Hefftler, 2015; Jančić 2015). As these new rights of national parliaments were already included in the Constitutional Treaty, there was academic commentary on these reforms before the Lisbon Treaty entered into force, with most of these publications rather sceptical of the EWM (e.g. Rittberger, 2005, 181-192; Kiiver, 2006, 153-168; Raunio, 2005; 2007; Barrett, 2008b).

${ }^{2}$ The function of recruiting, socializing and training ministers does not apply directly to EU affairs, as domestic legislatures do not recruit or elect members of the Commission or the 
persons for any positions in the EU institutions. On the other hand, the EU has introduced a new dimension to the activity of national parliaments by facilitating more active interparliamentary networking, both bilateral - between individual parliaments or between a national parliament and the EP - and multilateral, with the latter exercised mainly through COSAC (The Conference of Parliamentary Committees for Union Affairs of Parliaments of the European Union). The EWM fosters interparliamentary contacts, as it requires coordination among the 28 national parliaments to meet the thresholds for yellow and orange cards (Pintz, 2014; Cooper, 2015). While approaching parliamentary functions from somewhat different perspectives, Raunio (2011) and Sprungk (2013) provide more elaborate discussions of the functions of national parliaments in EU politics.

${ }^{3}$ Obviously one can argue that such a dichotomous approach to parliamentary functions is arbitrary or too simplistic, especially as MPs are basically always representing citizens in their work. For example, MPs can be considered to be representing their constituents when scrutinizing EU legislation in the EACs. Alternatively one can argue that plenary debates should be seen primarily as form of government scrutiny as opposed to linking with citizens and aggregating their interests. Similar problems, however, exist with other categorizations. Notably, given the increasing involvement of the executive in preparing legislative proposals, the functions of controlling government and of legislating have practically become indistinguishable. ${ }^{4}$ For example, according to Kiiver (2012) the real added value of the EWM lies in the justification it requires the Commission to provide for legislative proposals. Cooper $(2006 ; 2012)$ has also stressed the interaction between national parliaments and the Commission, with both sides engaging in constructive argumentation or deliberation about EU governance. 
${ }^{5}$ According to Cooper (2013), the EWM implies that the EU is now a 'tricameral' system, with the 'real' virtual third chamber co-existing alongside the Council and the EP. An alternative view is provided by Winzen (2013a) who does not see the mechanism as a form of interparliamentary cooperation. According to Winzen national parliaments agreed to the EWM because, apart from being completely voluntary, it in fact is compatible with practices of domestic oversight and can be carried out as part of the normal EU scrutiny process.

${ }^{6}$ Apart from Miklin (2013), who indicates that interparliamentary networking has improved government scrutiny in Austria, we are not aware of any empirical studies linking interparliamentary cooperation to government control.

${ }^{7}$ We are not denying that EWM matters can be less technical and more salient, particularly for individual parties. For example, Monti II was certainly salient for many centre-left parties with close ties to trade unions.

${ }^{8}$ We acknowledge that both European level treaties and national constitutions do provide national parliaments rather strong participation rights in euro crisis or euro area decision-making, with the Fiscal Compact even including an interparliamentary conference ('Article 13 conference'). However, as is the case with overall scrutiny of EU affairs, strong constitutional rights do not necessarily produce strong engagement or control. 


\section{References}

Auel, K. (2007) Democratic Accountability and National Parliaments: Redefining the Impact of Parliamentary Scrutiny in EU Affairs. European Law Journal 13(4): 487-504.

Auel, K. and Christiansen, T. (eds.) (2015) After Lisbon: National Parliaments in the European Union. West European Politics 38(2): 261-281.

Auel, K. and Höing, O. (2014) Parliaments in the Euro Crisis: Can the Losers of Integration Still Fight Back? Journal of Common Market Studies 52(6): 1184-1193.

Auel, K. and Höing, O. (2015) National Parliaments and the Eurozone Crisis: Taking Ownership in Difficult Times? West European Politics, 38(2): 375-395.

Auel, K. and Raunio, T. (eds.) (2014) Connecting with the Electorate? Parliamentary Communication in EU Affairs. Journal of Legislative Studies 20(1): 1-12.

Bagehot, W. (1867) [2009] The English Constitution. Oxford: Oxford University Press.

Barrett, G. (ed.) (2008a) National Parliaments and the European Union: The Constitutional Challenge for the Oireachtas and Other Member State Legislatures. Dublin: Clarus Press. 
Barrett, G. (2008b) "The King is Dead, Long Live the King”: The Recasting by the Reform Treaty of the Provisions of the Constitutional Treaty Concerning National Parliaments. European Law Review 33(1): 66-84.

Barrett, G. (2012) Monti II: The Subsidiarity Review Process Comes of Age ... Or Then Again Maybe it Doesn't. Maastricht Journal of European and Comparative Law 19(4): 595-603.

Bellamy, R. and Kröger, S. (2014) Domesticating the Democratic Deficit? The Role of National Parliaments in the EU's System of Governance. Parliamentary Affairs 67(2): 437-457.

Benz, A. (2004) Path-Dependent Institutions and Strategic Veto Players: National Parliaments in the European Union. West European Politics 27(5): 875-900.

Benz, A. (2013) An Asymmetric Two-Level Game: Parliaments in the Euro Crisis. In B. Crum and J.E. Fossum (eds.) Practices of Inter-parliamentary Coordination in International Politics: the European Union and beyond. Colchester: ECPR Press, pp. 125-140.

Bruter, M. (2009) Time Bomb? The Dynamic Effect of News and Symbols on the Political Identity of European Citizens. Comparative Political Studies 42(12): 1498-1536. 
Caramani, D., Deegan-Krause, K. and Murray, R. (2011) Political Data in 2010.

European Journal of Political Research 50(7-8): 869-887.

Christiansen, T., Högenauer, A-L. and Neuhold, C. (2014) National Parliaments in the post-Lisbon European Union: Bureaucratization rather than Democratization? Comparative European Politics 12(2): 121-140.

Cooper, I (2006) The Watchdogs of Subsidiarity: National Parliaments and the Logic of Arguing in the EU. Journal of Common Market Studies 44(2): 281-304.

Cooper, I. (2012) A 'Virtual Third Chamber’ for the European Union? National Parliaments after the Treaty of Lisbon. West European Politics 35(3): 441-465.

Cooper, I. (2013) Bicameral or Tricameral? National Parliaments and Representative Democracy in the European Union. Journal of European Integration 35(5): 531-546.

Cooper, I. (2015) A yellow card for the striker: national parliaments and the defeat of EU legislation on the right to strike. Journal of European Public Policy 22(10): 1406-1425.

COSAC (2013) Nineteenth Bi-annual Report: Developments in European Union Procedures and Practices Relevant to Parliamentary Scrutiny. Brussels: COSAC Secretariat. 
Cygan, A. (2013) Accountability, Parliamentarism and Transparency in the EU: The Role of National Parliaments. Cheltenham: Edward Elgar.

De Ruiter, R. (2013) Under the radar? National parliaments and the ordinary legislative procedure in the European Union. Journal of European Public Policy 20(8): 1196-1212.

De Vreese, C.H. (2001) 'Europe' in the News: A Cross-National Comparative Study of the News Coverage of Key EU Events. European Union Politics 2(3): 283-309.

De Vreese, C.H. (2007) A Spiral of Euroscepticism: The Media's Fault? Acta Politica 42(2-3): 271-286.

De Wilde, P. (2011) Ex Ante vs. Ex Post: The Trade-off Between Partisan Conflict and Visibility in Debating EU Policy-formulation in National Parliaments. Journal of European Public Policy 18(5): 672-689.

De Wilde, P. (2012) Politicisation of the EU Budget: Conflict and the Constraining Dissensus. West European Politics 35(5): 1075-1094.

De Wilde, P. (2014) The Operating Logics of National Parliaments and Mass Media in the Politicisation of Europe. Journal of Legislative Studies 20(1): 46-61. 
Deubner, C. (2013) The Difficult Role of Parliaments in the Reformed Governance of the European Economic and Monetary Union. Foundation for European Progessive Studies (FEPS) Study No. 19, August 2013.

Eriksen, E.O. and Fossum, J.E. (2002) Democracy through Strong Publics in the European Union? Journal of Common Market Studies 40(3): 401-424.

Fabbrini, F. and Granat, K. (2013) "Yellow Card, But No Foul": The Role of the National Parliaments under the Subsidiarity Protocol and the Commission Proposal for an EU Regulation on the Right to Strike. Common Market Law Review 50(1): 115-144.

Finke, D. and Dannwolf, T. (2013) Domestic scrutiny of European Union politics: Between whistle blowing and opposition control. European Journal of Political Research 52(6): 715-746.

Føllesdal, A. and Hix, S. (2006) Why There Is a Democratic Deficit in the EU: A Response to Majone and Moravcsik. Journal of Common Market Studies 44(3): 533-562.

Gattermann, K. and Hefftler, C. (2015) Beyond Institutional Capacity: Political Motivation and Parliamentary Behaviour in the Early Warning System. West European Politics 38(2): 305-334. 
Goldoni, M. (2014) The Early Warning System and the Monti II Regulation: The Case for a Political Interpretation. European Constitutional Law Review 10(1): 90-108.

Hefftler, C., Neuhold, C., Rozenberg, O. and Smith, J. (eds.) (2015) The Palgrave Handbook of National Parliaments and the European Union. Basingstoke: Palgrave Macmillan.

Hooghe, L. and Marks, G. (2009) A Postfunctionalist Theory of European Integration: From Permissive Consensus to Constraining Dissensus. British Journal of Political Science 39(1): 1-23.

Högenauer, A-L. and Neuhold, C. (2015) National Parliaments after Lisbon: Administrations on the Rise? West European Politics 38(2): 335-354.

Jančić, D. (2012) The Barroso Initiative: Window Dressing or Democracy Boost? Utrecht Law Review 8(1): 78-91.

Jančić, D. (2015) The game of cards: National parliaments in the EU and the future of the early warning mechanism and the political dialogue. Common Market Law Review 52(4): 939-976.

Kahn, J. (1997) Budgeting Democracy: State Building and Citizenship in America 18901928. Ithaca: Cornell University Press. 
Karlas, J. (2012) National Parliamentary Control of EU Affairs: Institutional Design after Enlargement. West European Politics 35(5): 1095-1113.

Kiiver, P. (2006) The National Parliaments in the European Union: A Critical View on EU Constitution-Building. The Hague: Kluwer Law International.

Kiiver, P. (2012) The Early Warning System for the Principle of Subsidiarity:

Constitutional theory and empirical reality. London: Routledge.

King, A. (1976) Modes of Executive-Legislative Relations: Great Britain, France, and West Germany. Legislative Studies Quarterly 1(1): 11-36.

Maatsch, A. (2014) Are we all austerians now? An analysis of national parliamentary parties' positioning on anti-crisis measures in the eurozone. Journal of European Public Policy 21(1): 96-115.

Mair, P. (2007) Political Opposition and the European Union. Government and Opposition 42(1): 1-17.

Maurer, A. and Wessels, W. (eds.) (2001) National Parliaments on their Ways to Europe: Losers or Latecomers? Baden-Baden: Nomos. 
McCubbins, M.D. and Schwartz, T. (1984) Congressional oversight overlooked: Police patrols versus fire alarms. American Journal of Political Science 28(1): 165-179.

Miklin, E. (2013) Inter-parliamentary cooperation in EU affairs and the Austrian Parliament: Empowering the Opposition? Journal of Legislative Studies 19(1): 22-41.

Miklin, E. (2014) EU Politicisation and National Parliaments: Visibility of Choices and Better Aligned Ministers? Journal of Legislative Studies 20(1): 78-92.

Moravcsik, A. (2006) What Can We Learn from the Collapse of the European Constitutional Project? Politische Vierteljahresschrift 47(2): 219-241.

Neuhold, C. and Strelkov, A. (2012) New opportunity structures for the "unusual suspects"? Implications of the Early Warning System for the role of national parliaments within the EU system of governance. OPAL Online Paper Series 2012/4.

Norton, P. (1993) Does Parliament Matter? Hemel Hempstead: Harvester Wheatsheaf.

O'Brennan, J. and Raunio, T. (eds.) (2007) National Parliaments within the Enlarged European Union. From 'Victims' of Integration to Competitive Actors? London: Routledge. 
Packenham, R. (1970) Legislatures and Political Development. In: A. Kornberg and L.D. Musolf (eds.) Legislatures in Developmental Perspective. Durham, N.C.: Duke University Press, pp. 521-582.

Paulo, M.T. (2012) National Parliaments in the EU: after Lisboa and beyond subsidiarity - The (positive) side-effects and (unintended) achievements of the Treaty provisions. OPAL Online Paper Series 2012/5.

Peters, J. (2009) The Role of National Parliaments, Checks and Balances between EU and the Member States. In: L. Verhey, P. Kiiver and S. Loeffen (eds.) Political Accountability and European Integration. Groningen: Europa Law Publishing, pp. 33-47.

Pintz, A. (2014) National Parliaments Overcoming Collective Action Problems Inherent in the Early Warning Mechanism: The Cases of Monti II and EPPO. LUISS School of Government Working Paper Series SOG-WP 22/2014.

Puntscher Riekmann, S. and Wydra, D. (2013) Representation in the European State of Emergency: Parliaments against Governments? Journal of European Integration 35(5): 565-582.

Raunio, T. (2005) Much Ado About Nothing? National Legislatures in the EU Constitutional Treaty. European Integration online Papers 9(9) (http://eiop.or.at/eiop/texte/2005-009a.htm) . 
Raunio, T. (2007) National legislatures in the EU Constitutional Treaty. In: J. O’Brennan and T. Raunio (eds.) National Parliaments within the Enlarged European Union: From 'victims' of integration to competitive actors? London: Routledge, pp. 79-92.

Raunio, T. (2011) The Gatekeepers of European Integration? The Functions of National Parliaments in the EU Political System. Journal of European Integration 33(3): 303-321.

Rittberger, B. (2005) Building Europe's Parliament: Democratic Representation Beyond the Nation-State. Oxford: Oxford University Press.

Rittberger, B. and Winzen, T. (2015) Parlamentarismus nach der Krise: Die Vertiefung parlamentarischer Asymmetrie in der reformierten Wirtschafts- und Währungsunion. Politische Vierteljahresschrift 56(3): 430-456.

Sprungk, C. (2013) A New Type of Representative Democracy? Reconsidering the Role of National Parliaments in the European Union. Journal of European Integration 35(5): 547-563.

Tans, O., Zoethout, C. and Peters, J. (eds.) (2007) National Parliaments and European Democracy: A Bottom-up Approach to European Constitutionalism. Groningen: Europa Law Publishing. 
Tweede Kamer (2011) Bovenop Europa: Evaluatie van de versterkte EU-ondersteuning van de Tweede Kamer, 2007-2011. Tweede Kamer der Staten-Generaal, Den Haag (http://birdsong.eu/assets/files/PDF/Bovenop\%20Europa.pdf.).

Van Middelaar, L. (2009) De Passage naar Europa. Geschiedenis van een Begin. Brussel: Historische Uitgeverij.

Wendler, F. (2013) Challenging Domestic Politics? European Debates of National Parliaments in France, Germany, and the UK. Journal of European Integration 35(7): 801-817.

Wessels, W., Rozenberg, O., Van Den Berge, M., Hefftler, C., Kreilinger, V. and Ventura, L. (2013) Democratic Control in the Member States of the European Council and the Euro zone summits. European Parliament, Directorate-General for Internal Policies, Policy Department C: Citizen's Rights and Constitutional Affairs.

Winzen, T. (2013a) Beyond the Decline of Parliament: European Integration and National Parliamentary Democracy. PhD dissertation, ETH Zürich.

Winzen, T. (2013b) European integration and national parliamentary oversight institution. European Union Politics 14(2): 297-323. 


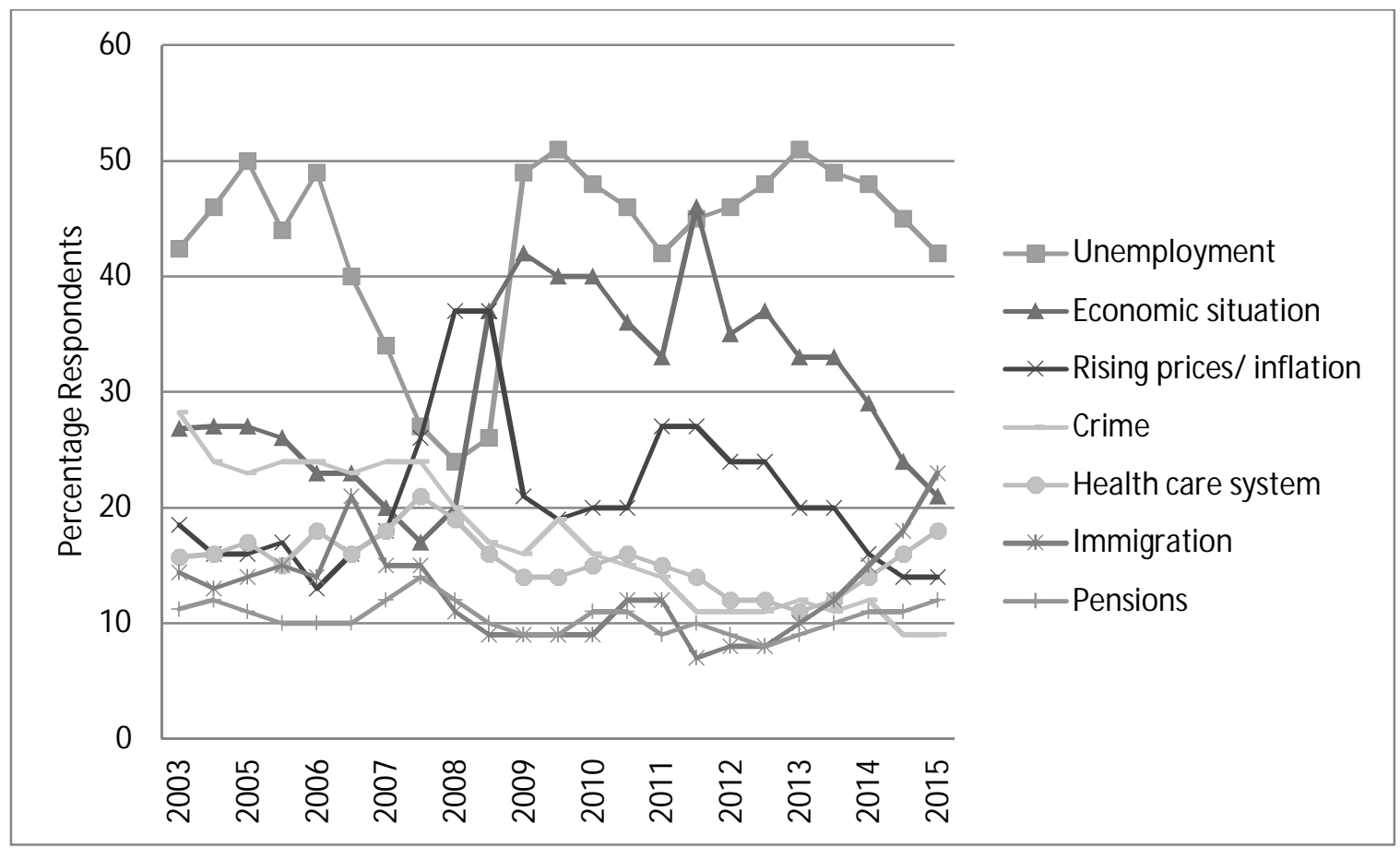

Figure 1: Topics of citizens' concern in the EU. Legend ordered according to descending average percentage respondents over the entire period.

Source: Eurobarometer: 'What do you think are the two most important issues facing (OUR COUNTRY) at the moment (MAX. 2 ANSWERS POSSIBLE)'. 
Table 1: Newspaper articles on yellow cards (source: Lexis Nexis)

\begin{tabular}{|c|c|c|c|}
\hline & & $\begin{array}{c}\text { Monti II } \\
(1 \mathrm{Apr}-30 \text { Sep } \\
\text { 2012) }\end{array}$ & $\begin{array}{c}\text { EPPO } \\
(1 \mathrm{Jul} 2013-28 \mathrm{Feb} \\
2014)\end{array}$ \\
\hline \multirow[t]{3}{*}{ UK } & The Guardian & 0 & 0 \\
\hline & The Financial Times & 0 & 0 \\
\hline & The Times & 0 & 0 \\
\hline \multirow[t]{2}{*}{ Ireland } & The Irish Independent & 0 & 0 \\
\hline & The Irish Times & 0 & 0 \\
\hline \multirow[t]{2}{*}{ France } & Le Monde & 1 & 0 \\
\hline & Le Figaro & 0 & 0 \\
\hline \multirow[t]{3}{*}{ Germany } & taz & 0 & 0 \\
\hline & Die Welt & 0 & 0 \\
\hline & Die Zeit & 0 & 0 \\
\hline \multirow[t]{2}{*}{ Austria } & Der Standard & 0 & 0 \\
\hline & Die Presse & 0 & 0 \\
\hline \multirow[t]{2}{*}{ Netherlands } & NRC Handelsblad & 1 & 3 \\
\hline & De Volkskrant & 0 & 0 \\
\hline
\end{tabular}

Search terms 01-04-2012 - 30-09-2012: 'yellow card” AND 'Monti II' OR ‘yellow card' AND ‘European Commission' OR ‘yellow card’ AND ‘national parliaments' in English, German, French, and Dutch.

Search terms 01-07-2013 - 28-02-2014: 'yellow card' AND 'European Public Prosecutor's Office' OR ‘yellow card' AND ‘European Commission' OR ‘yellow card' AND 'national parliaments' in English, German, French, and Dutch. 